\title{
HEPATITIS B- A KILLER STUDY OF AWARENESS AND PRACTICE AMONG DENTAL STUDENTS REGARDING HEPATITIS B INFECTION AND PREVENTION
}

\author{
Satyajit Sundar Ray1, Satyajit Pattnaik2, Anil Kumar Sharma ${ }^{3}$ \\ ${ }_{1}^{1}$ Associate Professor, Department of Community Medicine, Hi-Tech Medical College, Rourkela. \\ ${ }^{2}$ Associate Professor, Department of Community Medicine, GEMS, Srikakulam. \\ 3Professor, Department of Community Medicine, Hi-Tech Medical College, Rourkela.
}

ABSTRACT

\section{BACKGROUND}

Hepatitis B is one of the major infectious diseases of mankind globally. The risk of occupational exposure to HBV, especially among students in health professions is a major concern. Awareness regarding this serious preventable disease was lacking among them. This study was conducted to assess the level of awareness and practice among dental students regarding hepatitis B infection and prevention.

\section{MATERIALS AND METHODS}

A cross-sectional study was conducted from March 2014 to April 2014. A total of 269 undergraduate dental students were included. Data were collected by self-administered structured questionnaire and analysed by using Epi Info 3.5.1.

\section{RESULTS}

Response of students regarding transmission- Hepatitis B was transmitted by sex (84.4\%), contaminated blood and body fluid $(85.9 \%)$ and by unsterilised syringes, needles and surgical instruments (95.9\%). Regarding diagnosis, treatment and PEP- $95.9 \%$ said hepatitis B was diagnosed by hepatitis markers test, $90 \%$ said that vaccination was the choice for treatment of hepatitis B, 97\% said that vaccination was the main source of post exposure prophylaxis and $95.5 \%$ said that HBIg was used for post exposure prophylaxis. Good knowledge score was significantly higher among female students $(p=0.038)$, students aged more than 20 years $(p=0.046)$ and interns $(p=0.018)$. Fully vaccination status was significantly higher among interns $(p=0.028)$ and students who had good knowledge score ( $\mathrm{p}=0.025)$.

\section{CONCLUSION}

This study showed that overall awareness regarding hepatitis B was quite good among dental students, but there was a gap in practice as $47.6 \%$ students were not vaccinated or partially vaccinated against Hepatitis B. So we recommend that all students in the health profession should be vaccinated prior to their entry into professional practices.

\section{KEYWORDS}

Hepatitis B Awareness, Dental Students, Hepatitis B Vaccination and Practice.

HOW TO CITE THIS ARTICLE: Ray SS, Pattnaik S, Sharma AK. Hepatitis B- a killer study of awareness and practice among dental students regarding hepatitis B infection and prevention. J. Evolution Med. Dent. Sci. 2017;6(91):6460-6463, DOI: $10.14260 /$ jemds/2017/1404

\section{BACKGROUND}

Hepatitis B is one of the major infectious diseases of mankind globally; $66 \%$ of global population are living in areas with high level of hepatitis B infection $1 ; 10 \%-15 \%$ of HBV carriers of the world resides in India. ${ }^{2}$ In India $2 \%$ to $5 \%$ of general population and in South East Asian Region 5\% to 10\% of adult population was chronically infected. ${ }^{3}$ It is estimated that more than 2 billion people worldwide have current or past hepatitis B infection including 240 million chronic carriers and 686,000 deaths each year from cirrhosis and hepatocellular carcinoma. ${ }^{4}$ Among HCWs, prevalence of Hepatitis B is 2 - 10 times higher as compared to the general population globally. 5 Health workers are vulnerable to Hepatitis B infection, as they are in direct contact with patients and involved in different procedures like blood

'Financial or Other Competing Interest': None.

Submission 31-08-2017, Peer Review 11-11-2017,

Acceptance 18-11-2017, Published 27-11-2017.

Corresponding Author:

Dr. Satyajit Pattnaik,

Associate Professor,

Department of Community Medicine,

GEMS, Srikakulam.

E-mail: drsatyajitpatnaik@gmail.com

DOI: $10.14260 /$ jemds/2017/1404

\section{(c) (1) (3) $\Theta$}

transfusion, injections and surgical operations in their practices. In developing countries improper medical waste disposal, use and handling of unsterilised and contaminated medical equipment are mainly contributed to higher prevalence of HBV infection among HCWs.6,7 This can be handled effectively by proper hospital waste management, by the use of gloves, sterilised medical equipment and vaccination. ${ }^{8}$ But different studies showed that there was a clear gap of awareness and practice among students towards HBV infection. Therefore, this study was carried out to assess the degree of awareness and practice among dental students regarding hepatitis $\mathrm{B}$ infection and prevention.

\section{Aims and Objectives}

To study awareness level and practice among dental students regarding hepatitis $\mathrm{B}$ transmission and prevention.

\section{MATERIALS AND METHODS}

This cross-sectional study was conducted among undergraduate dental students at Kalinga Institute of Dental Sciences, Bhubaneswar from March to April 2014, which was approved by Institutional Ethics Committee. A total of 269 undergraduate dental students participated in the study. The study tool used was a self-administered structured 
questionnaire. Students from $3^{\text {rd }}$ year to interns were included as study population; $1^{\text {st }}$ and $2^{\text {nd }}$ year students were excluded from the study as they begin their clinical rotation duty from $3^{\text {rd }}$ year onwards. In the lecture theatres questionnaire was administered to the students who gave consent for the study, which was collected after it had been completed. The questionnaire was used to collect information about the socio-demographic characteristics of student and awareness among dental students regarding hepatitis B transmission and prevention. Each correct answer was given a score of ' 1 ', while a wrong answer or an unanswered was given a score of ' 0 '. Student's knowledge was classified to three levels; a total score of 0 - 6 was regarded as poor knowledge, 7 - 12 as acceptable knowledge and 13 and above as good knowledge. The data were analysed using Epi Info 3.5.1. Descriptive and analytical statistical methods were used for data analysis. Descriptive statistical method was used for determining frequencies and percentages and Chi-square test was used for determination of associations between categorical variables. A $p$ value of $\leq 0.05$ was regarded as statistically significant.

\section{RESULTS}

\begin{tabular}{|c|c|c|}
\hline Variables & No. & Percentage (\%) \\
\hline \multicolumn{3}{|c|}{ Sex } \\
\hline Male & 117 & 43.5 \\
\hline Female & 152 & 56.5 \\
\hline \multicolumn{3}{|c|}{ Age } \\
\hline $19-20$ & 114 & 42.4 \\
\hline $21-23$ & 142 & 52.8 \\
\hline $24-26$ & 13 & 4.8 \\
\hline \multicolumn{3}{|c|}{ Study Year } \\
\hline $3^{\text {rd }}$ year & 94 & 34.9 \\
\hline $4^{\text {th }}$ year & 88 & 32.7 \\
\hline Intern & 87 & 32.4 \\
\hline \multicolumn{3}{|c|}{$\begin{array}{c}\text { Table 1. Baseline Characteristics of } \\
\text { the Study Participants }\end{array}$} \\
\hline
\end{tabular}

Table 1 depicts 269 undergraduate dental students; from $3^{\text {rd }}$ year to intern were participated in the study, out of which $43.5 \%$ were male and $56.5 \%$ were female. $95.2 \%$ students were in the age group of 19 - 23 years.

\begin{tabular}{|c|c|c|c|}
\hline Variables & $\begin{array}{c}\text { Yes } \\
\text { N (\%) }\end{array}$ & $\begin{array}{c}\text { No } \\
\text { N (\%) }\end{array}$ & $\begin{array}{c}\text { Not Sure } \\
\text { N (\%) }\end{array}$ \\
\hline \multicolumn{3}{|c|}{ Knowledge about transmission } \\
\hline $\begin{array}{c}\text { Transmission of hepatitis } \\
\text { B by sexual contact }\end{array}$ & $227(84.4)$ & $24(8.9)$ & $18(6.7)$ \\
\hline $\begin{array}{c}\text { Transmission of hepatitis } \\
\text { B by unsterilised syringes, } \\
\text { needles and surgical } \\
\text { instruments }\end{array}$ & $258(95.9)$ & $10(3.7)$ & $1(0.4)$ \\
\hline $\begin{array}{c}\text { Transmission of hepatitis } \\
\text { B by contaminated blood } \\
\text { and body fluid }\end{array}$ & $231(85.9)$ & $31(11.5)$ & $7(2.6)$ \\
\hline $\begin{array}{c}\text { Transmission of hepatitis } \\
\text { B by casual contact such as } \\
\text { hand shaking }\end{array}$ & $29(10.8)$ & $238(88.5)$ & $2(0.7)$ \\
\hline
\end{tabular}

\begin{tabular}{|c|c|c|c|}
\hline $\begin{array}{l}\text { Transmission of hepatitis } \\
\text { B by food }\end{array}$ & $40(14.9)$ & $227(84.4)$ & $2(0.7)$ \\
\hline $\begin{array}{c}\text { Vertical transmission of } \\
\text { hepatitis B from mother to } \\
\text { child }\end{array}$ & $210(78.1)$ & $28(10.4)$ & $31(11.5)$ \\
\hline $\begin{array}{c}\text { Transmission of hepatitis } \\
\text { B by HBV carriers }\end{array}$ & $227(84.4)$ & $32(11.9)$ & $10(3.7)$ \\
\hline \multicolumn{4}{|c|}{ Knowledge about diagnosis, treatment and complication } \\
\hline $\begin{array}{l}\text { Hepatitis B is diagnosed } \\
\text { by hepatitis markers test }\end{array}$ & $258(95.9)$ & $8(3)$ & $3(1.1)$ \\
\hline $\begin{array}{l}\text { Hepatitis B is diagnosed } \\
\text { by medical history }\end{array}$ & $41(15.2)$ & $228(84.8)$ & $0(0)$ \\
\hline $\begin{array}{l}\text { Hepatitis B is treated by } \\
\text { vaccination }\end{array}$ & $242(90)$ & $23(8.6)$ & $4(1.4)$ \\
\hline $\begin{array}{l}\text { Hepatitis B is treated by } \\
\text { immunotherapy }\end{array}$ & $210(78.1)$ & $57(21.2)$ & $2(6.7)$ \\
\hline $\begin{array}{l}\text { Hepatitis B is treated by } \\
\text { antiviral therapy }\end{array}$ & $53(19.7)$ & $209(77.7)$ & $7(2.6)$ \\
\hline $\begin{array}{l}\text { Hepatitis B infection } \\
\text { causes liver cancer }\end{array}$ & $225(83.6)$ & $41(15.3)$ & $3(1.1)$ \\
\hline \multicolumn{4}{|c|}{$\begin{array}{l}\text { Knowledge about post exposure prophylaxis (PEP) and } \\
\text { prevention }\end{array}$} \\
\hline $\begin{array}{l}\text { Hepatitis B vaccine (HBV) } \\
\text { used for PEP }\end{array}$ & $261(97)$ & $7(2.6)$ & $1(0.4)$ \\
\hline HBIG used for PEP & $257(95.5)$ & $9(3.4)$ & $3(1.1)$ \\
\hline $\begin{array}{l}\text { Antiviral therapy used for } \\
\text { PEP }\end{array}$ & $58(21.5)$ & $206(76.6)$ & $5(1.9)$ \\
\hline $\begin{array}{c}\text { Hepatitis B Vaccine } \\
\text { prevents hepatitis B } \\
\text { infection }\end{array}$ & 264 (98.1) & $5(1.9)$ & $0(0)$ \\
\hline $\begin{array}{c}\text { Screened blood } \\
\text { transfusion prevents } \\
\text { hepatitis B infection }\end{array}$ & $260(96.6)$ & $8(4)$ & $1(0.4)$ \\
\hline $\begin{array}{c}\text { Hygiene prevents hepatitis } \\
\text { B infection }\end{array}$ & $13(4.8)$ & $255(94.8)$ & $1(0.4)$ \\
\hline \multicolumn{4}{|c|}{$\begin{array}{c}\text { Table 2. Knowledge of Hepatitis B among the Study } \\
\text { Participants }\end{array}$} \\
\hline
\end{tabular}

Table 2 reflects the knowledge of students about transmission, diagnosis, treatment, complication, PEP and prevention of Hepatitis B. Regarding the knowledge about transmission, the study participants told that HBV is transmitted by unsafe sexual contact $(84.4 \%)$, unsterilised syringes, needles and surgical instruments (95.9\%), contaminated blood and body fluid (85.9\%), vertical transmission from mother to child $(78.1 \%)$, HBV carriers $(84.4 \%)$ and casual contact such as hand shaking $(88.5 \%)$ and food (84.4\%) did not transmit the infection.

In terms of knowledge about diagnosis, treatment and complication of hepatitis B, $95.9 \%$ of study participants told hepatitis B was diagnosed by hepatitis markers test, $90 \%$ of study participants agreed that hepatitis B was treated by vaccination and immunotherapy (78.1\%), not by antiviral therapy $(77.7 \%)$ and $83.6 \%$ of study participants knew chronic hepatitis B infection can lead to liver cancer.

On assessing the knowledge on post exposure prophylaxis (PEP) and prevention, 97\% of study participants acknowledged that hepatitis B vaccine was used for PEP and 95.5\% told hepatitis B immunoglobulin was used, but for 
prevention of infection screening for blood transfusion (96.6\%) and hepatitis B vaccine (98.1\%) was required.

\begin{tabular}{|c|c|c|c|}
\hline \multirow[b]{2}{*}{ Variables } & \multicolumn{2}{|c|}{ Knowledge } & \multirow[b]{2}{*}{ P value } \\
\hline & $\begin{array}{l}\text { Acceptable } \\
(7-12) \text { N (\%) }\end{array}$ & $\begin{array}{c}\text { Good } \\
(\geq 13) \mathrm{N}(\%)\end{array}$ & \\
\hline \multicolumn{4}{|c|}{ Gender } \\
\hline Male (117) & $35(29.9)$ & $82(70.1)$ & \multirow{2}{*}{0.038} \\
\hline Female (152) & $29(19.7)$ & $123(80.3)$ & \\
\hline \multicolumn{4}{|c|}{ Age in Years } \\
\hline$\leq 20(114)$ & $34(29.8)$ & $80(70.2)$ & \multirow{2}{*}{0.046} \\
\hline$>20(155)$ & $30(19.4)$ & $125(80.6)$ & \\
\hline \multicolumn{4}{|c|}{ Study Year } \\
\hline $\begin{array}{c}3^{\text {rd }} \text { and } 4^{\text {th }} \text { year } \\
(182)\end{array}$ & 51 (28.3) & 131 (71.7) & \multirow{2}{*}{0.018} \\
\hline Intern (87) & $13(14.5)$ & $74(85.5)$ & \\
\hline Table 3. Asso & ion of Variab & ith Knowle & Status \\
\hline
\end{tabular}

Table 3 depicts good knowledge score was significantly higher among female students $(p=0.038)$, students aged more than 20 years $(p=0.046)$ and interns $(p=0.018)$.

\begin{tabular}{|c|c|c|c|}
\hline \multirow{2}{*}{ Variables } & \multicolumn{2}{|c|}{$\begin{array}{c}\text { Vaccination against HBV (3 } \\
\text { Doses) }\end{array}$} & \multirow{2}{*}{$P$ value } \\
\hline & Yes N (\%) & No N (\%) & \\
\hline \multicolumn{4}{|c|}{ Study Year } \\
\hline $\begin{array}{c}3^{\text {rd }} \text { and } 4^{\text {th }} \text { year } \\
(182)\end{array}$ & 87 (47.8) & 95 (52.2) & \multirow[t]{2}{*}{0.028} \\
\hline Intern (87) & $54(62.1)$ & $33(37.9)$ & \\
\hline \multicolumn{4}{|c|}{ Knowledge } \\
\hline Acceptable (64) & $23(35.9)$ & $41(64.1)$ & \multirow{2}{*}{0.025} \\
\hline Good (205) & $118(57.6)$ & $87(42.4)$ & \\
\hline
\end{tabular}

Table 4 shows full vaccination status was significantly higher among interns $(\mathrm{p}=0.028)$ and students who had good knowledge score $(p=0.025)$.

\section{DISCUSSION}

Before widespread of HBV vaccination of health care workers, transmission of infection from patients to health care providers was common. Since long health care related transmissions have been recognised as a significant source of HBV infection, especially in developing countries. So, assessing the awareness of health care providers is a useful step to design health intervention methods and public health policies.

A high proportion of study participants (76.2\%) had good knowledge score about HBV, which was more in comparison to the studies conducted by Samir M et al (14\%), ${ }^{9}$ Wadi FH et al $(49.3 \%)^{10}$ and Velvzhi $G$ et al $(72 \%),{ }^{11}$ but low in comparison to the study conducted by Singh A et al (86.7\%). ${ }^{12}$

Majority of study participants said correctly hepatitis B is transmitted by sexual contact (84.4\%), by unsterilised syringes, needles and surgical instruments (95.9\%) and by contaminated blood and body fluid (85.9\%), which was supported by the study conducted by Singh A et al (74\%, $83 \%, 87 \%), 12$ Hussain SF et al $(94.4 \%, 95.9 \%, 98.8 \%), 13$ Velvzhi G et al $(76.5 \%, 92 \%, 89.5 \%)^{11}$ and Abdela A et al (84.1\%, 96.7\%, 97.2\%). ${ }^{14}$

Most of the study participants (95.9\%) said that for diagnosis of hepatitis B markers test was used, which was supported by the study conducted by Hussain SF et al $(98.5 \%)^{13}$ and the guidelines given by WHO regarding hepatitis B. ${ }^{15} 83.6 \%$ of the study participants were aware that liver cancer may be a complication of hepatitis B infection, which was backed up by the studies conducted by Abdela A et al $(81.3 \%),{ }^{14}$ Velvzhi $G$ et al $(87 \%)^{11}$ and Hussain SF et al $(99.4 \%, 97.9 \%){ }^{13}$

Majority of the study participants said that vaccine (97\%) and immunoglobulin (95.5\%) were used for PEP, which was correctly acknowledged by the study conducted by Hussain SF et al $(97.1 \%, 91.8 \%) .{ }^{13}$ Most of the study participants said that vaccination $(98.1 \%)$ and screening blood transfusions (96.6\%) can prevent transmission of hepatitis B, which was supported by the studies conducted by Abdela A et al $(84.6 \%),{ }^{14}$ Paul P et al (86\%), ${ }^{16}$ Velvzhi G et al (93\%) ${ }^{11}$ and Hussain SF et al $(99.4 \%, 97.9 \%) .{ }^{13}$

There was statistically significant association between knowledge scores with gender, age and study year of students. Good knowledge score was significantly higher among female students, age more than 20 years and interns. Similar studies by Abdela A et al ${ }^{14}$ and El-Nasser GA et al ${ }^{17}$ showed no statistically significant association between knowledge scores with age and gender of the study participants, but the study by Samir M et $\mathrm{al}^{9}$ showed good knowledge score was significantly higher among older students and clinical year students.

HBV vaccination rate was significantly higher among interns (which was in agreement with the study by Samir M et al, ${ }^{9}$ but in disagreement with the studies by Velvzhi $\mathrm{G}$ et $\mathrm{al}^{11}$ and Singh A et $\mathrm{al}^{12}$ ) and those who had good knowledge (which was in agreement with the studies by Samir M et al, ${ }^{9}$ Velvzhi $\mathrm{G}$ et $\mathrm{al}^{11}$ and Wadi FH et $\mathrm{al}^{10}$ ).

\section{Limitations}

It covered a relatively small sample of dental students only. It did not cover other HCWs who were at high risk for HBV infection. The data were obtained by questionnaire, and therefore there could be a recall bias of the participants. The relatively small sample makes it difficult to detect factors that have statistically significant association with students' knowledge and vaccination status.

\section{CONCLUSION}

In this study, high proportion of study participants had good knowledge score which was encouraging, as knowledge was usually the first step towards modification of a desirable behaviour. But despite good knowledge, only 52.4\% study participants were fully vaccinated against Hepatitis B. The low vaccination rate could be attributed to two main factors. Firstly, vaccination against HBV was not introduced to the National Immunisation Program at that time. Secondly, HBV vaccination was not routinely provided to the students.

\section{Recommendation}

Poor compliance to hepatitis B vaccination is an issue that deserves serious attention, for which all students should be routinely vaccinated upon entry into the dental college to decrease the burden of the disease as they were exposed to the risk factors frequently in their day-to-day activities. There is a need for health education campaigns for health workers, so that they can understand the risks that they are exposed to based on the nature of their work. 


\section{REFERENCES}

[1] Park K. Park's textbook of Preventive and social medicine, 24th edn. Banarsidas Bhanot 2017: P. 228.

[2] Puri P. Tackling the hepatitis B disease burden in India. J Clin Exp Hepatol 2014;4(4):312-9.

[3] WHO. Guidelines for prevention care and treatment of persons with chronic hepatitis B infection. WHO 2015.

[4] WHO. Hepatitis B, Fact Sheet. No. 204, June 2016.

[5] West DJ. The risk of hepatitis B infection among health professionals in the United States: a review. Am J Med Sci 1984;287(2):26-33.

[6] Prüss-Üstün A, Rapiti E, Hutin Y. Estimation of the global burden of disease attributable to contaminated sharps injuries among health-care workers. Am J Ind Med 2005;48(6):482-90.

[7] Taneja N, Biswal M. Safe disposal of infectious wasteIndian perspective. J Hosp Infect 2009;62(4):525-6.

[8] World Health Organization. Health Care Worker Safety. http://www.who.int/occupational_health/activities/1 am_hcw.pdf.

[9] Othman SM, Saleh AM, Shabila NP. Knowledge about hepatitis B infection among medical students in Erbil city, Iraq. European Scientific Journal 2013;3:299-305.

[10] Wadi FH. Knowledge and practices of health care workers about hepatitis B in Erbil city. Unpublished Thesis. Baghdad: Iraqi Board for Medical Specializations 2012.

[11] Velvzhi G, Senthil K, Sucilathangam G, et al. Knowledge and attitude of medical students towards hepatitis B infection. Int J Curr Microbiol App Sci 2016;5(6):570-6.
[12] Singh A, Jain S. Prevention of hepatitis B-knowledge and practices among medical students. Indian Medical Gazette 2012;2:52-6.

[13] Hussain SF, Ahmad SR, Muslehuddin OM, et al. Knowledge, attitude and practice regarding hepatitis $\mathrm{B}$ among medical students. Int J Community Med Public Health 2016;3(11):2977-81.

[14] Abdela A, Woldu B, Haile K, et al. Assessment of knowledge, attitudes and practices toward prevention of hepatitis B virus infection among students of medicine and health sciences in Northwest Ethiopia. BMC research notes 2016;9:410.

[15] World Health Organization on behalf of Ministry of health and family welfare, Government of India: operational guidelines for hepatitis B vaccine introduction in the universal immunization program. 2011.

http://www.searo.who.int/india/topics/routine_imm unization/Operational_Guidelines_for_HepatitisB_vacc ine_introduction_in_UIP_2011.pdf?ua=1

[16] Paul P, Arumugam B. Knowledge and awareness regarding hepatitis $\mathrm{B}$ infection among medical and dental students: a comparative cross sectional study. Int J Res Med Sci 2015;3(9):2352-6.

[17] El-Nasser GA. Assessment of students' knowledge and attitude toward hepatitis $\mathrm{B}$ and $\mathrm{C}$ in Sohag University/Egypt. Kufa Journal for Nursing Sciences 2013;3(1):1-14. 